\title{
CONSUMERS BEHAVIOUR AS REFLECTION OF FOOD SECURITY AT REGIONAL LEVEL IN HONDURAS
}

\author{
Anna TOLMÁČI ${ }^{*}$ \\ Comenius University, Faculty of Natural Sciences, Department of Regional Geography, Protection and \\ Planning of the Landscape, Ilkovičova 6, 84215 Bratislava, Slovakia, email: anna.tolmaci@uniba.sk

\section{Ladislav TOLMÁČI} \\ Comenius University, Faculty of Natural Sciences, Department of Regional Geography, Protection and \\ Planning of the Landscape, Ilkovičova 6, 84215 Bratislava, Slovakia, email: ladislav.tolmaci@uniba.sk
}

Citation: Tolmáči, A., \& Tolmáči L. (2018). CONSUMERS BEHAVIOUR AS REFLECTION OF FOOD SECURITY AT REGIONAL LEVEL IN HONDURAS. GeoJournal of Tourism and Geosites. 22(2), 359-372. https://doi.org/10.30892/gtg.22207-294

\begin{abstract}
The primary driver of food security or insecurity is the food system which creates a framework of approach to study and also solving this issue in region. The case study is analyzing the availability and accessibility of food in settlements Sangrelaya and Cocalito in Honduras. The local food system and its functioning are characterized on the base of research and analysis of food consumption practices and the food situation perception. The research results show that the inhabitants of villages Sangrelaya and Cocalito suffer from food insecurity mostly due to the threat of spatial and economic insufficient access to food.
\end{abstract}

Key words: local food, food security, food system, consumption, Honduras

\section{INTRODUCTION}

Food security is a pressing issue in the global as well as regional life (Atkins \& Bowler, 2001; Lawrence et al, 2010; Gibson, 2012; FAO; Reid, 2012). When studying food security, it seems as most comprehensive to apply a system approach. Food system is considered as a major actor of food security, respectively food security is a main outcome of food system. (Sobal et al., 1998; Ericksen, 2008; Rutten et al., 2011; Hammond \& Dubé, 2012; Fonte, 2002). The model of conceptualized food system could explain in the best way the structure, relationships and functioning of food systems (Sobal et al., 1998). Food system according to our conception includes production, processing, distribution, sale and consumption of food (Kneen, 1989; Hartog, 1995; Sobal et al., 1998; Atkins \& Bowler, 2001; Bentay, 2005; Ericksen, 2008; etc.). Individual activities are interconnected as chain-, circle or as network- relationships (Lang et al., 2012; Sobal et al., 1998). It is clearly not a closed system, it imports and exports food all the time (Lang et al., 2012). The level of food security is directly related to functioning of various

\footnotetext{
* Corresponding author
} 
subsystems of the studied food system. By analysing them it could lead to the identification of possible problems, for example hunger or food insecurity (Ericksen, 2008; Rutten et al., 2011). However, the structure and dynamics of the food system, which is the central player in food security, is strongly influenced by the level of economic development and direction of economic growth of the country (Odekon, 2006; Hammond \& Dubé, 2012). Consumers are the last part in the food chain but directly or not directly connected with all subsystems of food system in region/ nation. The behaviour of consumers can influence food system, on other hand reflect the functioning of interconnected individual parts of food system. Food and gastronomy can play also an important role in the sector of tourism López-Guzmáne al., 2018; Privitera et al., 2018). In our research we focused on Honduras which still belongs to developing countries. Food insecurity is a problem of this country.

More global organizations, which monitor the food situation in Honduras, are confident about it. The World Organization for Food and Agriculture (FAO) in its studies on food security in Honduras states that between 1990 and 2005, the proportion of undernourished fell from $19 \%$ to $14 \%$, which means improving the food situation of the population. However, food safety analysis, carried out in the country indicated that the population of Honduras diet is one-sided, since they receive $80 \%$ of calories from 10 kinds of foods, with a high percentage of corn and beans (FAO, 2011). FAO statistics indicate top 10 commodities available for consumption in Honduras, in the first place is mentioned corn, then there are sugar, cereals, palm oil, rice, poultry, beans, green bananas, sweet yellow bananas, sweeteners and others. The average energy consumption per capita per day was for the last reported period in $2009-2687 \mathrm{kcal}$. The largest share in the consumption of food are grains, they made up nearly 50\%. There belongs rice, corn and wheat. Meat represents just $5.6 \%$ of consumption. Sugar has a relatively high proportion of consumption - 16.3\%. The prevalence of malnutrition from a lack of nutrients in the diet is permanently decreasing. In the years 2010-2012 amounted to 10\%. Compared to the years 1999-2001 it means a decrease of 6\%. The country is the recipient of food aid. Items of it vary considerably. In 2013 it was delivered to the country four thousand tonnes of grain, ten years back in 2003 it was 56000 tons. The World Food Programme (WFP, 2014) based on its analysis and criteria assessed Honduras as a country in need of food aid. According to estimates, almost 1.5 million of its inhabitants are facing starvation. Chronic malnutrition affects rural areas and $48.5 \%$ of the population. Honduras is considered one of the most vulnerable countries in the world, due to natural disasters. Our research focused on the analysis of the food system in relation to food security in the micro-region of Sangrelaya and Cocalito (Honduras).

One of the partial steps in studying food system was a behavioural research of food consumption at the household level. The aim was to find out how the consumers act as the last link in the food system. Through their consuming practises we can identify connections between parts of food chain in the region. Consuming practices also indicate gaps and deficits in local food system. Using a questionnaire, we determined how individuals / households victual, buy food, produce food, how they perceive the food situation in their household and how they perceive food security in their region.

\section{Food security as a dimension of food system}

International Food and Agriculture Organization (FAO) adopted at the World Food Summit in 1996, based on diplomatic agreements, a definition of food security: "Food security is a condition where all people, at all times, have physical, social and economic access to sufficient, safe and nutritious food which meets their dietary needs and food preferences for an active and healthy life" (FAO, 2013). Food security could be in the simplest way introduced as a model of four pillars of availability, accessibility, utility and 
stability/vulnerability (Jones, 2013; Gibson 2012; FAO, 2008; Riela, 1999). Food security metrics may focus on these domains or some combination of these domains (Tansey et al., 1995; Jones el al., 2013). Food availability means the quantity, type and quality of foods that are regionally available (domestic production, imports, food aid). Food accessibility is an economic and physical possibility to get supplies of food (income, purchasing power, transport and market infrastructure). Especially the food acquisition behaviors of households are important for translating physical and economic access to food into food security (Jones el al., 2013). Utility means the ability of individuals and households to consume food and use their nutritional value. Stability/vulnerability is an economic and political background that allows the functioning of the previous three pillars (Atkins \& Bowler, 2001; Ericksen, 2008; FAO, 2008; Lawrence el al., 2010; Gibson, 2012). All these components together create subsystems of the food system (food availability = production, distribution, exchange; accessibility = affordability, allocation, markets, acquisition, transportation, preferences; utilization = nutritional value, social value, food safety, consumption) and can be analyzed at any regional level (Ericksen, 2008; Rutten et al., 2011). It follows that study of food systems requires a system approach to understand the complexity of the concept of food security (Maxwell, 1995; Neff, 2009; Tolmáči, 2017). System approach is useful in its methods to analyse components, relations, interaction, structure and behaviour of system (Matlovič \& Matlovičová, 2015, Marsden \& Morley, 2014). The importance of system approach lies in the ability to orientate in loads of facts and information which are in some way interconnected (Černík \& Viceník, 2011).

\section{METHODS AND DATA}

Our research aim was to monitor the food security through analyzing food production, aspects of food consumption and diet of inhabitants in the developing micro region of Sangrelaya and Cocalito, district Colón, Honduras. Key dimension of food security in our research were availability, economic and spatial accessibility and consumption of food. The analysis of these various subsystems of local food system led to the identification of factors that most threaten the availability and accessibility of food for the inhabitants of this region. This examined issue offers a broad range of research questions. Its diapason is overlapping spatial, economic, social, legislative, medical and prognostic aspects. They can be summarized in three lines of selective questions:

Table 1. Research questions

\begin{tabular}{|l|}
\hline Availability: How much and what kind of food are in the region intended to be eaten? \\
\hline Do residents produce local food (plants and animals)? \\
How does the distribution of food work? \\
What are the store possibilities of sellers and households? \\
Do residents receive food aid? \\
\hline Accessibility: What is the spatial and economic access to food for the population? \\
\hline Where do residents of researched region buy food? \\
Are in the researched area accessible grocery stores? \\
How do residents receive funds to buy food? \\
What is the price of food? \\
What are the economic conditions of the local population? \\
Consumption: What is the typical diet of the population and what is the real \\
situation in the nutrition of the population? \\
\hline What are the main components in the diet of the local population? \\
Which food/nutrients are dominant in consumption of the population? \\
Which food components/nutrients are absent in the diet of the population? \\
Which socio-economic factors have dominant effects on food intake of the local population? \\
\hline
\end{tabular}


Our timetable for implementing the research was planned as a series of interrelated sequential steps. For a thorough treatment of the research subject and for greater clarity on issues of social properties in the selected area (and for better use in practice) we applied qualitative and quantitative approaches. For the collection of data and information, we used basic techniques - fieldwork, participant observation, questionnaire and interview. Participant observation is a useful method of learning on the studied area, e. g. the living conditions of its population and community relations. Prolonged and intensive contact with the region is essential for the study of the phenomenon of hunger (hidden hunger) in the natural environment and in the search of local causalities. We searched the number of grocery stores directly in the region, their range and food prices. This pre research led (after collecting and analyzing the gained information) to creation of questionnaire. Using this questionnaire we conducted a behavioural research in selected micro-regions. The aim was to determine the self-production of food, the current way, frequency and variability of food consumption, purchasing power, preferences in food purchases, subjective perception of the food situation of households, the relationship to each other and the acceptance of food aid (Table 2). The questionnaire contained more open (essay) questions. The questionnaire was distributed to inhabitants in the official language of the country, in Spanish. For a deeper understanding of the situation and to complete the picture of how is functioning the food system in the searched region/communities we then used a semi-structured interview. We conducted them with three representatives of communities (teacher, doctor and missionary). It completed our integrated view of the topic studied at the regional level.

Table 2. Selected indicators of food security

\begin{tabular}{|l|l|}
\hline Household/individual indicator & \multicolumn{1}{c|}{ Characteristic } \\
\hline Variability of food intake & $\begin{array}{l}\text { Food consumption of groups of fats, carbohydrates, } \\
\text { protein, dietary fiber, vitamins, minerals }\end{array}$ \\
\hline Frequency of food intake & $\begin{array}{l}\text { The number of meals consumed during day, composition } \\
\text { of the meals during the day/week, favourite foods }\end{array}$ \\
\hline Food self-sufficiency & $\begin{array}{l}\text { Local agricultural production - crops, fruits, vegetables, } \\
\text { breeding of domestic animals }\end{array}$ \\
\hline Shopping of food & $\begin{array}{l}\text { Location of shops, frequency of shopping, preferred food, } \\
\text { transportation of food }\end{array}$ \\
\hline Subjective perception of FS & $\begin{array}{l}\text { Perception of abundance or lack of food in household, } \\
\text { frequency of food shortages, possibly of hunger }\end{array}$ \\
\hline
\end{tabular}

In the case study we used the recommended methods for research of food security and nutrition of the population. These included: questionnaire, semistructured interviews, participant observation and analysis of the food system (Foran el al, 2014; Loring et al., 2013; EFSA, 2009; Gerster-Bentaya, 2005; Riely, 1999; Spišiak, 1985). The principal indicator for our research was the consumption of foods. It can be tracked at the individual level or at the household level. Traditional methods to track consumer habits are dietary records, dietary recalls, dietary diversity, household budget survey, food balance sheet, interview (Jones et al., 2013; EFSA, 2009; Riely, 1999; Spišiak, 1985). To retrospective category of methods, not entailing detailed description and weighing of consumed food, for preparing our questionnaire we included food frequency method and diet history method (Ferro-Luzi, 2002; EFSA, 2009). We collected most of our research data in during field work and from local institutions. Others we searched on internet and we used statistical data from international organisation as FAO, WHO and World Food Program. 


\section{Sample}

Municipalities of Sangrelaya and Cocalito in Colón in Honduras are spatially interconnected. Therefore it is appropriate to consider their cadastre as one research area. Residents of both villages are from one ethnic group of Garifuna people, sharing the same natural, economic, social, cultural, and social conditions (Blouet et al., 2005). They use the same infrastructure, schools, church facilities, retail, health services, attending joint cultural events and having similar lifestyle. Although these two communities belong to two separate self-governing territorial divisions, in spite of the fact that they have the characteristics of a single community. The aims of our research are connected to the functioning of food system in these villages. The latest available statistics on the number of inhabitants are from 2010. The village Sangrelaya has registered 973 residents, the village Cocalito 621 inhabitants. Children and teenagers under 18 years made up a very high proportion of the total population (by age of living in Honduras $45 \%$ of the population under 18 years old). We, definitely, can talk about very young population. Exact statistics on the age structure of the population of both settlements are not available. For the questionnaire survey, we applied two criteria concerning age and region: respondents must be from the village Sangrelaya and/or Cocalito and have more than 18 years. The upper age limit has not been established. In the event that we take into account the fact that the village is about $40-45 \%$ of the population younger than 18 years, the actual number of residents who might be involved in our research was about 650. Subsequently, at a confidence interval 8 and at $95 \%$ confidence level we distributed questionnaires to 122 respondents. The number of selected respondents equals to desired number of respondents needed to maintain the representativeness and credibility of research from which we could obtain generally valid conclusions and evaluations for the whole region.

\section{Results of the questionnaire: Food consumption behaviour of respondents}

In the questionnaire we focused on the composition of the diet, frequency of consumption and purchasing food, place of shopping, preference of purchased and consumed meals and the overall perception of the food situation of the population and food aid. Meat, except of fish, is for local inhabitants not a very common component of meals. Chicken is from farmed animals the most often consumed item (30.3\%), beef and pork are consumed only in exceptional cases. Fish is part of meals most commonly in $68.4 \%$ of cases. For many people it is a usual part of everyday diet. Fishes are the basic of the diet of local residents. Meat consumption occurs more than once a week in $38 \%$ of the population. Fish meals are consumed seven days a week by $43 \%$ of inhabitants.

Fish and seafood (turtles, crabs, shrimps etc.) are purchased in $84.2 \%$ cases mostly fresh directly from the fishermen in the village or on the beach just after fishing. Some of respondents (6.6\%) fish by themselves. Other meat, especially chicken, is purchased in pulperias (60.5\%). Pork and beef are mostly from domestic breeding of more wealthy local residents. They slaughtered the animals and during the day, they sell it out. Domestic breeding is not typical, just $56.6 \%$ of respondents breeds some animal. The most widespread is poultry - hens and chickens has $87 \%$ of breeders, $30 \%$ have pigs and only $7 \%$ have cattle. The less affordable foods include milk and dairy products. More than half of respondents (56.6\%) consume it just 1-2 times a week. 13\% of them do not consumed it at all. Dairy products mentioned were milk, cheese and butter. Regional milk suppliers are farmers in $\mathbf{2 2 . 4 \%}$ of cases, but most dairy products are purchased in local Pulperias (51.3\%), or they are imported from the city of Tocoa and La Ceiba (11.8\%).

Vegetable consumption is one of the problems of the local inhabitants. It is very low. Vegetables are financially and geographically difficult accessible food components, 
even though it may be due to the natural conditions of the country incomprehensible. $26 \%$ respondents stated that they have no vegetables during the week time and $17 \%$ said that, in general, they consume it very rarely. Once or twice a week consumes vegetable $37 \%$ of respondents. Slightly better results were recorded for the consumption of fruit, but it also has its reserves, over 40\% of respondents consumed fruit only 1-3 times a week. Fruits are readily available, and they are included in dietary lists more often than vegetables, mainly because they are grown in this area more often. Cultivation of various crops was mentioned in questionnaires 23-times, fruit was included 45-times. Out of vegetables the locals cultivate less demanding crops such as yucca, corn, beans or green bananas called platano or guineos. Just few individuals grow tomatoes, peppers or carrots. Grown fruit species include mangoes, oranges, papayas, bananas and coconuts. The access to fruit and vegetables in local pulperias is very limited. Vegetables are mostly purchased in Tocoa (51.3\%) as well as fruit (45\%). The locals buy them sometimes from local producers. Fruit and vegetables are becoming more affordable for local residents through vendors who come to the village with the car fully loaded with goods.

Among residents, we further investigated the frequency of consumption of rice, potatoes, yucca, pasta and bread. Rice was the leading crop according the number of days it was consumed, and also according the number of respondents who consumed it. It was followed by bread and yucca. Pasta and potatoes were included in consumption pattern much less often. Rice dominates in overall dietary pattern of local inhabitants. Among the five most commonly consumed meals (food) $84.2 \%$ of respondents chose it as their top. The other four dishes in top 5 most frequent meals were: soup machuca (fish soup with banana and coconut, green bananas, tortillas (corn or wheat pancakes) and fish.

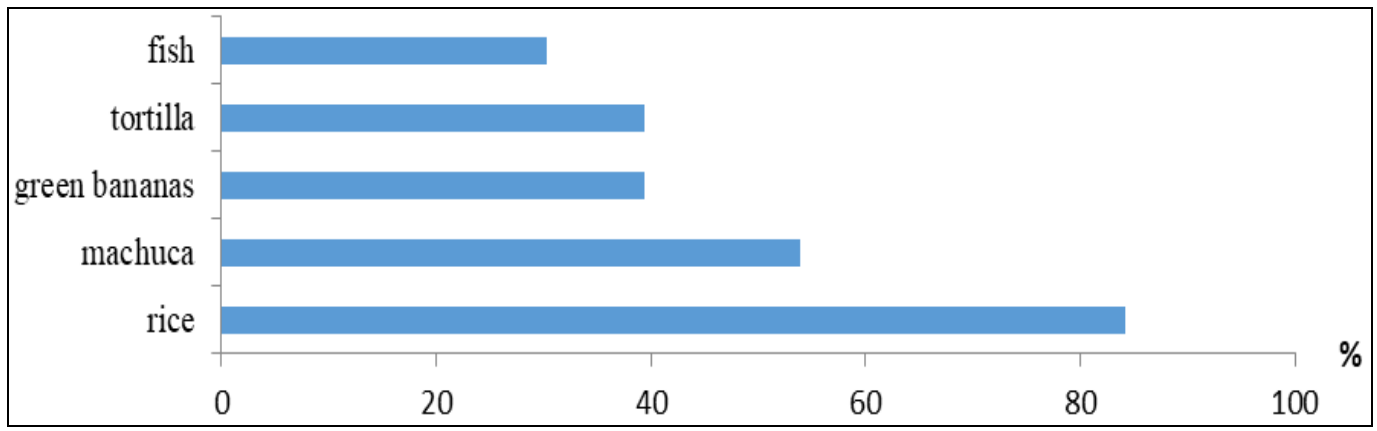

Figure 1. Ranking of the five most commonly consumed foods and dishes (Source: Field survey, 2013)

Respondents included among the 10 most frequently consumed food of this region also beans, seafood, chicken, yucca. This selection of the most commonly consumed foods in the region corresponds with the list of the most common food consumed by the people of Honduras by FAO (FAO, 2011). The survey was also focused on the structure and frequency of food consumption during the day. Three times daily consumes $80.3 \%$, two times a day $13.2 \%$ of respondents. For breakfast and dinner in consumption clearly dominated corn or wheat pancakes (tortillas), accompanied by eggs, beans and bananas. For lunch the most often choice was rice. It consumes about $72 \%$ of respondents, further fish, chicken, soup and bananas. One of the favourite foods of $54 \%$ respondents was soup "Machuca". The primary ingredients of it are: coconut water and fish.

They are simultaneously the most affordable raw materials, in economical and spatial sense of view in the region. In addition to food insecurity in the region there is a problem with drinking water also. In our survey $84,2 \%$ of respondents declared they do 
drink water from the public network, which is causing frequent digestive problems. Only 7.9\% of respondents do not drink this "public" water and purchase safe drinking water, mostly from water supplies. Locals like to drink sugary liquids (77.6\%), such as carbonated soft drinks and a variety of juices from own production.

A particular problem of food supplies in the region is food shopping. Due to incomplete and insufficient road infrastructure and isolation of the region is evident the pure availability of large shopping centres and supermarkets. In those centres costumers have not only more choice of food but the food is also two to three times cheaper than in small grocery shops in villages. Shopping outside the municipality was realized by $70 \%$ of respondents, out of which $79 \%$ of purchases took place in Tocoa. The rest of the respondents shop food in village Iriona, exceptionally, some manage to shop in San Pedro Sula (few hundred $\mathrm{km}$ away). The majority (45\%) can go to the city once a month, three times or more a month manage to go shopping only $12 \%$ of respondents. $16 \%$ of the respondents do shopping outside the village during the year very rarely. For example, teachers are going to the city of Tocoa every month for their wages and they used to shop food using this occasion. Therefore they have the highest frequency of shopping outside local villages. Outside the villages residents are usually buying vegetables, fruits and meat, because they are mostly in local Pulperías not available. Other purchased foods are mainly rice, flour, sugar and beans, because in supermarkets in the city they are cheaper. Out of total expenditures respondents spend the most money on: rice, meat, flour, sugar, fish and beans. These commodities dominate in the volume of purchased food and the frequency of purchases of the respondents also (Figure 2).

Figure 2. The most preferred food items in terms of price, volume and frequency of purchases (Source: Field survey, 2013)

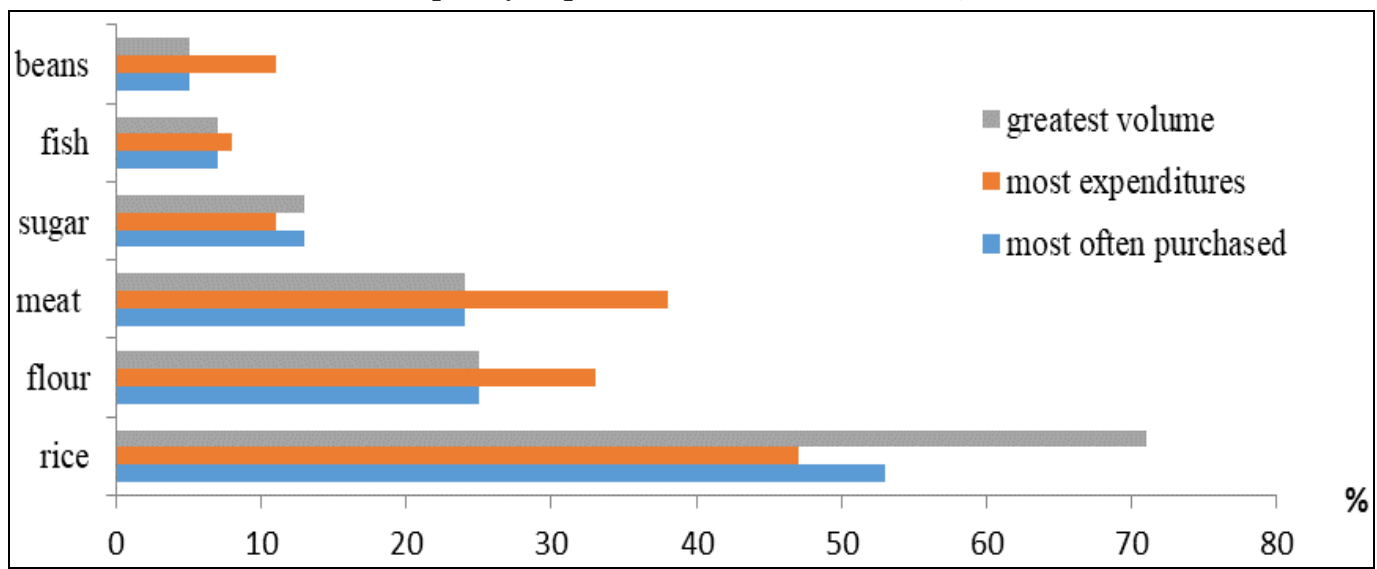

When asked in case they had more money what kind of food they would buy (they normally do not buy) the respondents answered: more vegetables (49\%) and fruit (34\%). Furthermore, they would purchase more milk, dairy products $(28 \%)$ and meat (22\%). Surprising was that $18 \%$ of respondents were attracted by cornflakes and cereals. Many would invest more money into basic foods that normally buy, but by buying them in larger quantities. The final part of the questionnaire was devoted to subjective evaluation of food availability according to their perception of food situation in the region. At the same time, we asked them, how they help each other at the time of crisis or hunger and food insecurity in the households. Most respondents (88\%) consider their situation to be unsatisfactory and think they do not have enough food. Only $9 \%$ of respondents consider 
the stock of their food supplies as satisfactory and diet as balanced. Satisfaction with food stock was expressed mostly by respondents with higher education and those who have permanent jobs and stable income (doctor, nurse and teachers). They consumed much more variable meals including vegetables and fruits.

Despite the high proportion of dissatisfied, only 4 respondents clearly stated that they were hungry because they do not have access to any meal. Over 90\% of respondents did not reply to this question at all or indicated that they did not felt hungry, which might suggest that the situation is not so critical and hunger due to lack of food in the acute form is not common. This statement was supported by the recorded responses to the next question, which revealed, that even if they do not have enough food, they often help each other and resolve the situation. Alternatively they have meals consisting of rubbed yucca or boiled rice. Over $60 \%$ of respondents have already been in situation, that they had no food, and someone helped them. $15.8 \%$ of respondents never needed food aid. In $46.5 \%$ of cases it was a family that helped and provided food for them. 23.3\% answered that their children helped them in times of need. 9.3\% said that they have got help from parents. Nothing extraordinary was to get help of neighbours, or help of friends. $23.4 \%$ of respondents got help from neighbours and 20.9\% were provided food from friends. Evidence that food aid is conceived as natural can be proven by the positive 95\% responses to the question whether they already gave food to someone because they did not have enough food and they have been threatened by hunger. Few people have obtained organized and institutionalized food aid (21\%), in almost $43 \%$ of these cases food aid was delivered by vincentic nuns (Sisters of Charity of Saint Vincent de Paul).

The rest received food aid from the state, for example, after the devastating hurricane, or they get aid from local parish or school.Respondents declared that food situation in the region is week or critical. According to them it is caused by lack of employment opportunities, low income, poverty, lack of privately owned land, uncultivated land etc. From the interviews it is clear that in the community there are people who suffer from hunger and malnutrition, vulnerable groups are single mothers with young children and the elderly because they do not have stable income. For local residents, it is very difficult to adopt a varied and balanced diet, because food is expensive and stores with a wider range of food supplies are distinct.

\section{Results of interviews: an opinions of community members on their food conditions}

During our research on food security and food availability/ accessibility in the region we have conducted three interviews with representatives of the local community teacher, missionary and doctor. All three live in the community and are familiar with the economic and social situation in the region, as well as its potential. They agreed that the food situation is difficult but not critical, such as in some regions of Africa. They think that the diet of local residents is nutritionally unbalanced and monotonous.

Meals consists mainly of yucca, corn cake, rice, beans, fish and occasionally poultry. It lacks fruit and vegetables. The problem is that people do not know the importance of a balanced diet, do not know even what that means. Monotonous diet does not supply them with essential vitamins and minerals. For example, children in the morning tend to take to school just a short casaba (kind of bread made from yucca). They do not feel hunger but they are not strong enough to study. The teacher indicated that they have difficulties to concentrate. They are not able to listen and they hardly think. Doctor also confirmed the problems with proper nutrition. She had evidence of four cases of severe child malnutrition, but many children, especially under the age of five years are referred as on the edge of malnutrition. She tried to teach young mothers and motivate them to care better for their children. The local teacher evaluated the food situation in the 
region by statement, "We have no problem with hunger, but we have a problem with food." In the community there are people, who do not have enough food, they are not hungry, but they have little food. This is called "a certain kind of hunger", which is found particularly in large families, which have 8, 9 to 14 children. It is estimated that enough food has about 30\% of families. He identifies two reasons of it. The first is the lack of jobs and unemployment. People catch fish and work on the farm as day workers, but this work is not stable. The second reason is the high illiteracy of the population. It is estimated that about $40 \%$ of the population cannot read or write. He observes as a problem also the accessibility and high distance to places with large shop where the food is cheaper than in the village. There are 16 grocery shops (pulperias) in the region, which is for the given number of inhabitants a lot. The problem is the variety, quality and price of products offered to them as a result of difficult access for vehicles to the region. Shopping in the city is more profitable but challenging mainly for transportation. Availability of food exacerbates the lack of paved roads and bridges. Their quality deteriorates during the rainy season. The missionary sees the food shortages in the villages. He considers as a drawback the reluctance of inhabitants to seek the way how to increase their standard of living. Many of them are satisfied only with the subsistence minimum they have. On the other hand, others would like to manage but do not have the funds to buy seeds, plants, animals or do not have land on which they could plant or graze cattle.

Agriculture is not the main source of livelihood, cultivation and farming is gaining nourishment for only a few people. There are several explanations. The big change came with the emergence of rich farmers. They bought land from local people and started to grow African palms on large plantations and had herds of cattle. A particular problem for locals is the agricultural practice. Growing vegetables and crops is for them very demanding and difficult. They need special assistance, someone who can explain them how to plant and how to care for plants. Breeding animals are introduced only minimally because they have no money for food or land. Interest in doing enterprise is declining, because there is a thread that someone will steal the harvest and it discourages them from agriculture. Especially the younger generation is losing interest to work in the domestic economy and is lacking knowledge of agricultural work. Residents of the region are recipients of food aid from several governmental and non-governmental initiatives. Children in school are supported already for eight years (from 2005) by the government's food aid program. Within it the school gets supplies of raw materials from which selected parents cook meals for the whole school. Special food programs are led by nuns. There are about 20 families included in it. For them they deliver at the end of each month some basic products such as sugar, oil, flour, rice etc. Activities under the direct supervision of Missioners include collection of food in the church once a month. At the same time they help to distribute food packages from the USA (Stop Hunger) for the poorest households. This initiative supported the region twice. Among residents there is a strong mutual sense for help. The community has expressed strong solidarity and loyalty.

The local missionary considers as major development boost for the region, which will also improve the availability of food, the improvement of the infrastructure (bridges and roads). It will connect the village with the other settlements and simplify the transport. Another challenge for the community is the electrification of the village, which will bring more changes. He says "We need to be part of Honduras". According to the missionary there is a chance to return to agriculture and it will bring positive changes. Missionaries in cooperation with the municipality want to start small agricultural projects that would be able to solve the subsistence nature of livelihood of the local population. Representatives of Health centre plan in cooperation with the mayor in Colon to create a supporting program, which will focus on the elimination of malnutrition. 


\section{Discussion: characteristics of food system in microregion Sangrelaya and Cocalito}

Here are listed the main problems in local food chain with affection on food security in researched area. The agricultural potential of the country is not fully utilized by local residents. Just few agricultural products originate from local production. They grow yucca, beans, rice, oranges, mango, avocado, coconut, bananas. Breeding is limited to poultry (hens and chickens). In few households they breed pigs. Cattle are breed only in wealthy farms. Subsistence fishing is the main activity of the primary sector. Fish is the most affordable and regional source of protein and nutrients. Fisheries is a very important component of the regional food system. People across the region rely on local seafood that they catch themselves for a significant portion of their diet (Mydlová, 2016; Loring, 2013). Most products, including the basic foodstuffs, are imported into the region. People are dependent on food distribution. Our research has shown that the biggest problem is the availability of fruits, vegetables, dairy, meat, especially pork and beef. Therefore, we think that all agricultural projects should be planned in order to fill the gap of these commodities. Nutrition of the population is based on rice, fish, yucca flour, bananas and chicken consumption. Vegetables are in dietary patterns completely absent or minimal. The reason is that vegetables, fruits and meat are in comparison to rice, fish, two-, threeand more times expensive. In the region is taken into account more the quantity than the quality and nutritional value of the food. The aim is not to be hungry. Graded yucca or boiled rice are often a way to fight hunger. Shopping in the village is possible only in small convenience stores - "pulperias". Most of them offer only basic products - rice, flour, oil, sugar, beans. More variable assortment, e. g. chicken, meat, etc., is only in three stores and very irregularly. Outside the village residents go shopping most often in the town of Tocoa. It is located $80 \mathrm{~km}$ (about three hours drive by car, depending the weather, season, adjustments of unpaved roads).

Distribution of food is, because of poor transportation conditions, complicated, especially when just minimum of local inhabitants own a car and the rest must use services of local carriers by sea, river or road (e.g. buses from the adjacent villages). In modern terminology of scientists we can call this region as "food desert" (Guy, 2007; Shaw, 2014; Eckert, Shetty, Meenar, in Reid, et al, 2016). To store the food (availability) is also complicated due to hot and humid climate. The region is located in the tropical zone with difficult climatic conditions. During the year, people face really high temperatures and humidity level at which food has a tendency to spoil. There is no electricity in the village. The residents produce energy by using diesel generators, but not every household is equipped with them. Moreover, such a source of energy is very expensive. It is for them impossible to constantly keep the food in cool conditions. A large stock of food requires refrigeration, but they cannot afford it. To preserve fish is easier, they salt or dry them. In this case we can result that the undeveloped transportation system and storage technologies of the place have significant impact on regional food system and food security (Eckert, Shetty, in: Reid, 2016).

In Honduras, not excluding the region of Sangrelayi and Cocalita, we can notice also the impact of globalization. It can be observed also in production, distribution and consumption of food. It could be indicated by an increase of the impact of the global food system and by the decline of the local food system. Local food system is typical by acting without necessary distribution of food over long distances and more direct relationship between producers and consumers (Lacy, 2000; Feagan, 2007; Reid et al., 2016). Great land owners and multinational agri-food companies are buying land and establishing large farms with hundreds of hectares for cultivation of bananas, African palms and other 
exotic agricultural commodities which are prioritized for export markets. They are using the existing land resources and do involve intensive deforestation, creating new farm land. The globalization trend has some considerable negative features. The export capacity of the country is increasing, but most of the profits end up in the hands of large commercial farmers, not small landowners. Connected with this process, the region of Sangrelaya and Cocalito face problems with agricultural production of local people. It reflects the decline in self-sufficiency in domestic consumption, which is very important. Another effect is the loss of biodiversity, which has negative impact on the climate (Atkins \& Bowler, 2001; George, 2010; Oosterveer \& Sonnenfeld, 2012).

\section{How to deal with food aid in undeveloped region}

Identifying the problem of food accessibility and availability plays a major role in determining the solutions that we can apply in order to evaluate hunger, malnutrition, and lack of available nutrition. In case if we only treat symptoms or misdiagnose problems, we do not make things better, but in fact it can be even worse (Corbert \& Fikker, 2009). Specifically concerning the provision of food aid around the world, involving governmental projects (Nováček, 2017) and NGO projects, it is necessary to carefully consider in what form it could be provided and what kind of food to choose (Klennert et al. 2005; UNAIDS; UNDP). This requires a thorough examination of the conditions in which people live. Identify regional particularities and way of life of the local inhabitants (Cruz, 2013). This applies especially to areas where people have access to certain types of food and they are not in acute danger of lack of food, as in our research region. Inhabitants of the analyzed areas in Honduras regularly consume rice, because it is financially very accessible (Basset \& Winter-Nelson, 2010). Paradoxically as food aid from international organization (Stop Hunger) they have been supplied with rice. This food aid just temporarily covers their own portion of cheap purchased rice. Aid package per head, however, was very small. These people are willing to accept anything. For packages of rice they were very grateful. But this food aid can cover just one dinner for a larger family. This aid had a very short-term effect. Its purpose was fulfilled. They eat up. It satisfied the donor. It remains questionable whether it fulfilled the true purpose of aid and to what extent it was effective. What would these people need is not only food aid but starting to create conditions for development, and not only in this community but everywhere in the whole region.

\section{CONCLUSIONS}

The aim of the research was to analyze the issue of the availability and accessibility of food on the micro-region level and to detect some basic general conclusions. The results of our research were conducted on the basis of a questionnaire survey and interviews. They confirmed that inhabitants of villages of Sangrelaya and Cocalito do experience food insecurity due to spatial and economic threat to gain food. Our basic assumption was confirmed, but two partial premises were not proven: self agricultural production of food is not the main source of the livelihood of local inhabitants. The majority of locals are not mployed and do not practice agriculture.

Community self-sufficiency in producing agricultural products (plant and animal) currently operates at a much lower level than we expected. Most of the food they consume comes from retail stores and are imported to the village. In the context of food security and for sake of improved food availability it was confirmed the need for development in the agricultural sector at the local level. The locals can work and obtain self-sufficient supplies from their own production. As the second unconfirmed assumption we consider the pattern of regular consumption of food, because over $80 \%$ of respondents declared, that they ate three times a day, which represents quite a high 
regularity. But compared with more economically developed regions they consume food less frequently and in smaller doses, so it can be stated that local residents due to limited budget do not have regular and sufficient supply of food. Other assumptions formulated as working premises were confirmed. Residents of Sangrelaya and Cocalito have insufficient variability of food (meals) and receive nutritionally unbalanced diet. From this case study it is evident that eating habits are determined by food availability in different regions of the world and of course specific situation of studied countries. Food security - in our research dominantly composed of food availability and food accessibility monitored through consumption practices - in the region is clearly affected by the socio-economic potential of the population, e. g. their employment, monthly income, number of household members, education and the distance of food selling units. It is also related to road infrastructure. Its improvement will in the future ensure better spatial accessibility of food and bring the expected economic development of the region. Our research can, for sure, have benefits for a particular community in Sangrelaya and general consequences also.

The locals can gain a much more realistic opinion on the state of food security in their region. They can get basic ideas on the scale of hunger and malnutrition problems. Described facts and conclusions can be used for a proactive approach in the fight against hunger and in developing appropriate strategies against food insecurity in the region. Our research results can be used for planning new projects that directly or indirectly affect the availability of food. It can also increase the effectiveness of existing or planned food aid by all organizations. The used research strategy can be applied to any developing and developed region (after modifications from the point of view of the specific conditions of the region under examination). A thorough analysis of the potential of the region and its citizens is a prerequisite to provide effective food aid and development cooperation. Basic SWOT analysis is able to assess what people really need, what are the priorities and possibilities to determine the most appropriate way (form) of action that will solve the problems in specific regions. But for appropriate changes and solution of many problems it would need a strong will and belief of many stakeholders at national and international level in the field of politics, economic and business conditions, education and other spheres with an impact on development and sustainability.

\section{Acknowledgement}

This work was supported by the VEGA grant agency entitled: Social, economic and environmental determinants of development and transformation of regions: regionalgeographical approach. No. 1/0540/16.

\section{REFERENCES}

Atkins, P., \& Bowler, I. (2011). Food in society: Economy, culture, geography. London: Arnold, 2011, ISBN 9780-340-72004-2.

Basset, T., \& Winter-Nelson, A. (2010). The Atlas of World Hunger. Chicago: University of Chicago Press, 2010. ISBN 978-0-226-03907-7.

Blouet, B.W., \& Blouet, O. (2005). Latin America and the Caribbean. A Systematic and Regional Survey. WILEY, ISBN 978-0-470-38773-3.

Corbet, S., \& Fikkert, B. (2012). Ked' pomoc škodí. Ako zmiernit chudobu bez ubližovania chudobným a vám samotným. [When help is harmful. To mitigate poverty without harming the poor and yourself]. Bratislava: Porta libri, ISBN 978-80-89067-70-1.

Cruz, D. (2013). Ayuda én Acción - Honduras. Línea de Base. Informe Final de la ADT7Cabo Camarón. [Help in action - Honduras. The basic line. Final report of ADT7Cabo Camarón]. Tegucigalpa, Junio de 2013.

Černík, V., \& Viceník, J. (2011). Úvod do metodológie spoločenských vied. [Introduction to the Methodology of Social Sciences]. Bratislava: Iris, ISBN 978-80-98256-79-2.

Ericksen, P. L. (2008). Conceptualizing food systems for global environmental change research. Global Environmental Change, 18 (2008), pp. 234-245. 
Feagan, R. (2007). The place of food: mapping out the local in local food systems. Sage: Progress in Human Geography 31(1), s. 23-42.

Ferro-Luzzi, A. (2002). Individual Food Intake Survey Methods. Keynote Paper at the International Scientific Symposium on Measurement and Assessment of Food Deprivation and Undernutrition, FAO Rome.

Fonte, M. (2002). Food System, Consumption Models and Risk Perception in Late Modernity. International Journal of Sociology of Agriculture and Food. Vol. 10. Issue 1, pp. 13 - 21. ISSN: 0798-1759.

Foran, T., Butler, J. R. A., Williams, L. J., \& Wanjura, W. (2014). Taking Complexity in Food System Seriosly: An Interdisciplinary Analysis. World Development Vol. 61, pp. 85-101.

George, C. (2010). Pravda o obchode. Skutočné dôsledky liberalizácie. [True on trade. The real consequences of liberisation]. Bratislava: Nadácia Pontis, 2011, ISBN 978-80-968229-4-2.

Gibson, M. (2012). The Feeding Of Nations: Re-defining food security for the 21st century. London: CRC Press, 2012, ISBN 978-1-4398-3951-5.

Guy, C. (2007). Planning for retail development. A critical view of the British experience. London: Routledge, 2007, ISBN 978-0-415-65087-8.

Hammond, R.A., \& Dubé, L. (2012). A systems science perspective and transdisciplinary models for food and nutrition security. PNAS. Vol. 109, No. 31. http://www.pnas.org/cgi/doi/10.1073/pnas.0913003109.

Hartog den, A.P., Staveren van, W.A., \& Brouwer, I. D. (1995). Manual for social surveys on food habits and consumption in developing countries. Pudoc Wageningen, The Netherlands, Margraf Verla.g

Jones, A. D., Ngure, F. M., Pelto, G., \& Young, S. L. (2013). What Are We Assessing When We Measure Food Security? A Compendium and Review of Curent Metrics. American Society for Nutrition. Adv. Nutr. 4: 481-505, DOI: 10.3945/an.113.004119.

Klennert, K., Bokeloh, G, Gerster-bentaya, M., \& Weingärtner, L. (2005). Achieving Food and Nutiotion Security. Felfafing: InWent, 2005, ISBN 3- 937235-71- X.

Lacy, W. (2000). Empowering communities through public work, science and local food systems: revisisting democracy and globalization. Rural sociology 65, 3-26.

Lang, T., \& Barling, D. (2012). Food security and sustainability: reformulating the debate. The Geographical Journal, Royal Geographical Society, Vol. 178, No. 4, December 2012, pp. 313-326.

Lawrence, G., Lyons, K., \& Wallington, T. (2010). Food security, nutrition and sustainability. UK: earthscan, 2010. ISBN978-1-84971-387-0.

Loring, P. A., Gerlach, S. C., \& Harrison, H. L. (2013). Seafood as local food: Food security and locally caught seafood on Alaska's Kenai Peninsula. Journal of Agriculture, Food Systems, and Community Development, 3(3), 13-41. http://dx.doi.org/10.5304/jafscd.2013.033.006.

López-Guzmán, T., Torres Naranjo, M., Perez-Galvez, J. C., \& Carvache Franco, W. (2018). Gastronomic Perception and Motivation of a Touristic Destination: The City of Quito, Ecuador, GeoJournal of Tourism and Geosites, Vol. 21, p. 61-73.

Marsden, T., \& Morley, A. (2014). Sustainable Food System. Building a New Paradigm. Oxon: Earthscan from Routledge. ISBN 978-0-425-63955-2.

Matlovič, R., \& Matlovičová, K. (2015). Geografické myslenie. [Geographical thinking]. Prešovská univerzita v Prešove. Fakulta humanitných a prírodných vied. ISBN 978-80-555-1416-1.

Maxwell, D. G. (1995). Measuring food insecurity: the frequency and severity of „,coping strategies“. Washington: International Food Policy Research Institute. FCND discussion paper no. 8.

McCann, G., \& McCloskey, S. (2009). Od lokálneho ku globálnemu. Klúčové rozdiely rozvojových štúdií. [From local to global. Key differences in development studies]. Bratislava: Nadácia Pontis, 2011, ISBN 978-80-968229-3-4.

Morgan, K., Marsden, T., \& Murdoch, J. (2006). Worlds of food: Place, power, and provenance in the food chain. Oxford: Osford University Press, ISBN 0-19-927158-5978.

Mydlová, A. (2012). Hlad vo svete a jeho príčiny. [Hunger in the world and its reasons]. Geographia Cassoviensis, Vol. 7, Issue 1/2012, $100-110$.

Mydlová, A. (2013). Honduras - tropická rozvojová krajina. Geografia, Vol. 21, Issue 1/2013, 4 - 9.

Mydlová, A. (2016). Analysis of Food Security in the Developing Regions of Sangrelaya and Cocalito in Honduras With a Focus on the Mission Aspect. Acta Missiologica. Vol. 10, Issue 2/2016, 67-83.

Neff, R. A., Palmer, A. M., McKenzie, S. E., \& Lawrence, R. S. (2009). Food Systems and Public Health Disparities. Journal of Hunger \& Environmental Nutrition, 4: 3, 282 - 314. DOI http://dx.doi.org/10.1080/19320240903337041.

Nováček, P. (2017). Možné rozvojové př́íležitosti v budoucím vývoji rozvojové spolupráce. Potential development opportunities fot future enhancement of development cooperation, Acta Missiologica, Vol. 11, Issue 1, p. 8-21.

Privitera, D., Nedelcu, A., \& Nicula, V. (2018). Gastronomic and food tourism as an economic local resource: case studies from Romania and Italy, GeoJournal of Tourism and Geosites, Vol. 21, p. 143-157.

Odekon, M. (2006): Encyclopedia of World Poverty. London: SAGE Publications, Volume 2: H-R, 455- 941, ISBN 1-4129-1807-3.

Oosterveer, P., \& Sonnenfeld, D. A. (2012). Food, Globalization and Sustainability. Abindon: earthscan, 2012, ISBN 978-1-84971-261-3. 
Reid, N., Gatrell, J. D., \& Ross, P. S. (2016). Local Food Systems In Old Industrial Regions. Concepts, Spatial Context, and Local Practices. New York: Routledge, ISBN 978-1-138-27897-4.

Riely, F., Mock, N., Cogill, B., Bailey, L., Kenefick, E. (1999). Food Security Indicators and Framework for Use in the Monitoring and Evaluation of Food Aid Programs. Food and Nutrition Technical Assistance Project (FANTA), Washington D.C.

Rutten, L. F., Yaroch, A. L., \& Story, M. (2011). Food Systems and Food Security: A Conceptual Model for Identifying Food System Deficiencies. Jurnal of Hunger Environmental Nutrition, 6:239-246, ISSN 1932-0248.

Shaw, H. J. (2014). The Consuming Geographies of Food. Diet, food desserts and obesity, Oxon: Routledge. ISBN 978-0-415-81870-4.

Sobal, J., Khan, L.K., \& Bisogni, C. (1998). A Conceptual Model of the Food and Nutritional System. Soc. Sci. Med. Vol. 47, No. 7, 853 \pm 863 .

Spišiak, P. (1985): Príspevok k priestorovému rozmiestneniu výživy obyvatel'stva. [Contribution to the spatial distribution of population nutrition]. In: Acta Facultatis Rerum Naturalium Universitatis Comenianae, Geographica Nr. 25, 53-68.

Tansey, G., \& Worsley, T. (1995). The Food System. A Guide. Earthscan. London, ISBN 978-1-85383-277-2

Tolmáči, A., \& Tolmáči, L. (2017). Teoretické východiská štúdia potravinovej bezpečnosti v rozvojových regiónoch sveta - aplikácia na región v Tanzánii. [Theoretical framework of the food security study in the developing regions of the world - application in the regions of Tanzania], Acta Missiologica, Vol. 11 , Issue $1 / 2017,65-85$.

Tolmáči, L. (2002). Dostupnost’ miest Slovenska. [Accessibility of Slovak towns]. Bratislava: MAPA Slovakia, ISBN 80-89080-40-5

Watts, M., \& Goodman, D. (1998). Globalising food: Agrarian questions and global restructuring. London: Routledge.

*** EFSA (2009). General principles for the collection of national food consumption data in the view of a panEuropean dietary survey. Parma: European Food Safety Authorit, EFSA Journal 2009; 7 (12): 1435.

*** FAO (2011). Value-chain Analysis of International Fish Trade and Food Security in the Republic of Honduras. www.fao.org/.../Honduras_Value_chain_analysis_Final_report_-_April_2011.doc.

*** FAO (2011). Food Security Indicators. http://www.fao.org/economic/ess/ess-fs/ess-fadata/en/ \#.Uyw $\mathrm{DDPl} 5 \mathrm{MrQ}$.

*** FAO (2013). Food security definition. http://www.fao.org/hunger/en/.

*** FAO (2013). Hunger Portal. http://www.fao.org/hunger/en/.

*** FAO (2013). The State of Food Insecurity in the World. Rome: FAO, ISBN 978-92-5-107316-2.

*** FAO (2013). Faostat Honduras. http://faostat.fao.org/CountryProfiles/Country_Profile/Direct.aspx? lang $=$ en\&area $=9$.

*** WFP (2009). Emergency Food Security Assesment Handbook. [online] Rím 2009.

https://www.cia.gov/library/publications/the-world-factbook/geos/ho.html. CIA. Honduras. The World Factbook.

http://www.fao.org/docrep/o13/al936e/al936eoo.pdf. FAO (2008). An Introduction to the Basic Concepts of Food Security.

http://www.garifuna.com/.The Garifuna Community.

http://www.unaids.org/en/regionscountries/countries/honduras/ UNAIDS. Honduras.

http://hdr.undp.org/en/countries/profiles/HND UNDP. Human Development Reports. Honduras.

http://home.wfp.org/stellent/groups/public/documents/manual_guide_proced/wfp203246.pdf

http://www.wfp.org/countries/honduras/overview WFP (2014). Honduras.

http://www.who.int/topics/nutrition/en/. WHO (2014). Nutrition.

Submitted:

22.12.2017
Revised:

14.05.2018
Accepted and published online 16.05.2018 